Pacific Journal of Mathematic 


\title{
ON A PAPER OF NIVEN AND ZUCKERMAN
}

\author{
J. W. S. CASSELS
}

1. Introduction. Let 'digit' mean an integer in the range $0 \leq a<10$. For digits $a_{1}, a_{2}, \cdots, a_{r} ; b_{1}, b_{2}, \cdots, b_{s}(s \geq r)$ and integer $m$, denote by

$$
R_{m}\left(a_{1}, \cdots, a_{r}, b_{1}, \cdots, b_{s}\right)
$$

the number of solutions of

$$
b_{n}=a_{1}, b_{n+1}=a_{2}, \cdots, b_{n+r-1}=a_{r} \quad(0<n<n+r \leq s ; n \equiv m \bmod r),
$$

so that

$$
0 \leq R_{m}\left(a_{1}, \cdots, a_{r} ; b_{1}, \cdots, b_{s}\right) \leq s-r+1 .
$$

Suppose that

$$
x_{1}, x_{2}, \cdots
$$

is an infinite sequence of digits. It has been shown [2] that if

$$
\lim _{N \rightarrow \infty} \frac{1}{N} \sum_{m=1}^{r} R_{m}\left(a_{1}, \cdots, a_{r} ; x_{1}, \cdots, x_{N}\right)=10^{-r}
$$

for all integers $r$ and digits $a_{1}, \ldots, a_{r}$, then

$$
\lim _{N \rightarrow \infty} \frac{1}{N} R_{m}\left(a_{1}, \cdots, a_{r} ; x_{1}, \cdots, x_{N}\right)=r^{-1} 10^{-r}
$$

for all integers $r, m$, and digits $a_{1}, \ldots, a_{r}$. A possibly simpler proof is as follows.

2. Proof. Let $\epsilon>0$ and digits $a_{1}, \cdots, a_{r}$ be given. The simple argument of Hardy-Wright [1] shows that if the integer $s$ is fixed large enough, then 
(4) $\quad \operatorname{Max}_{\mu}\left|R_{\mu}\left(a_{1}, \cdots, a_{r} ; b_{1}, \ldots, b_{s}\right)-\frac{s-r+1}{r 10^{r}}\right|<\epsilon(s-r+1)$

except for at most $\epsilon 10^{s}$ sets of digits $b_{1}, \cdots, b_{s}$. ('Exceptional' sets.) Thus, by $(2)$ with $b_{1}, \cdots, b_{s}$ for $a_{1}, \cdots, a_{r}$, the number of exceptional sets

$$
x_{t}, x_{t+1}, \cdots, x_{t+s-1} \quad(1 \leq t \leq N-s+1)
$$

is at most $2 \epsilon N$ for all large enough $N$.

On the other hand,

$$
(s-r+1) R_{m}\left(a_{1}, \cdots, a_{r} ; x_{1}, \cdots, x_{N}\right)
$$

differs from

$$
\sum_{t=1}^{N-s+1} R_{m-t+1}\left(a_{1}, \cdots, a_{r} ; x_{t}, \cdots, x_{t+s-1}\right)
$$

by at most $2 s^{2}$, since each solution of

$$
a_{1}=x_{n}, a_{2}=x_{n+1}, \cdots, a_{r}=x_{n+r-1}(s \leq n \leq N-s ; n \equiv m \bmod r)
$$

contributes exactly $s-r+1$ both to (6) and to (7). Hence, using the estimate (3) for the at most $2 \in N$ exceptional sets (5), and the estimate (4) for the others, we have

$$
\begin{aligned}
& \left|R_{m}\left(a_{1}, \cdots, a_{r} ; x_{1}, \cdots, x_{N}\right)-\frac{N-s+1}{r 10^{r}}\right| \\
& \leq \frac{2 s^{2}}{s-r+1}+\epsilon(N-s+1)+2 \epsilon N,
\end{aligned}
$$

and so

$$
\limsup _{N}\left|\frac{1}{N} R_{m}\left(a_{1}, \ldots, a_{r} ; x_{1}, \ldots, x_{N}\right)-r^{-1} 10^{-r}\right| \leq 3 \epsilon .
$$

Since $\epsilon$ is arbitrarily small, this proves (3) as required. 


\section{References}

1. G. H. Hardy and E. M. Wright, An introduction to the theory of numbers, First Edition, Oxford, 1938, $\$ 9.13$.

2. I. Niven and H.S. Zuckerman, On the definition of normal numbers, Pacific J. Math. 1 (1951), 103-110.

Trinity College,

Cambridge, ENgland 



\section{PACIFIC JOURNAL OF MATHEMATICS}

\section{EDITORS}

\section{R. M. RoBINSON \\ University of California Berkeley 4, California}

\author{
*R. P. Dilmorth \\ Califomia Institute of Technology \\ Pasadena 4, California
}

E. F. BeckenbaCh, Managing Editor

University of California

Los Angeles 24, California

${ }^{*}$ During the absence of Herbert Busemann in 1952.

\section{ASSOCIATE EDITORS}

$\begin{array}{llll}\text { R. P. DILWORTH } & \text { P. R. HALMOS } & \text { BØRGE JESSEN } & \text { J. J. STOKER } \\ \text { HERBERT FEDERER } & \text { HEINZ HOPF } & \text { PAUL LÉVY } & \text { E. G. STRAUS } \\ \text { MARSHALL HALL } & \text { R. D. JAMES } & \text { GEORGE PÓLYA } & \text { KÖSAKU YOSIDA }\end{array}$

\section{SPONSORS}

UNIVERSITY OF BRITISH COLUMBIA

CALIFORNIA INSTITUTE OF TECHNOLOGY

UNIVERSITY OF CALIFORNIA, BERKELEY

UNIVERSITY OF CALIFORNIA, DAVIS

UNIVERSITY OF CALIFORNIA, LOS ANGELES

UNIVERSITY OF CALIFORNIA, SANTA BARBARA

OREGON STATE COLLEGE

UNIVERSITY OF OREGON

\author{
UNIVERSITY OF SOUTHERN CALIFORNIA \\ STANFORD UNIVERSITY \\ WASHINGTON STATE COLLEGE \\ UNIVERSITY OF WASHINGTON \\ AMERICAN MATHEMATICAL SOCIETY \\ NATIONAL BUREAU OF STANDARDS, \\ INSTITUTE FOR NUMERICAL ANALYSIS
}

Mathematical papers intended for publication in the Pacific Journal of Miathematics should be typewritten (double spaced), and the author should keep a complete copy. Manuscripts may be sent to any of the editors. All other communications to the editors should be addressed to the managing editor, E. F. Beckenbach, at the address given above.

Authors are entitled to receive 100 free reprints of their published papers and may obtain additional copies at cost.

The Pacific Journal of Mathematics is published quarterly, in March, June, September, and December, by the University of California, Berkeley 4, California. The price per volume (4 numbers) is \$8.00; single issues, $\$ 2.50$. Special price to individual faculty members of supporting institutions and to individual members of the American Mathematical Society: $\$ 4.00$ per volume; single issues, $\$ 1.25$.

Subscriptions, orders for back numbers, and changes of address should be sent to the publishers, University of California Press, Berkeley 4, California.

Printed at Ann Arbor, Michigan. Entered as second class matter at the Post Office, Berkeley, California.

\section{UNIVERSITY OF CALIFORNIA PRESS • BERKELEY AND LOS ANGELES}




\section{Pacific Journal of Mathematics}

\section{Vol. 2, No. $4 \quad$ April, 1952}

Shmuel Agmon, On the singularities of Taylor series with reciprocal coefficients .................................... 431

Richard Arens, A generalization of normed rings ............... 455

Iacopo Barsotti, Intersection theory for cycles of an algebraic variety . . . . 473

Leonard M. Blumenthal, Two existence theorems for systems of linear inequalities ..................................... 523

Frank Herbert Brownell, III, Translation invariant measure over separable Hilbert space and other translation spaces................. 531

J. W. S. Cassels, On a paper of Niven and Zuckerman ............... 555

Nelson Dunford, Spectral theory. II. Resolutions of the identity .......... 559

Eugene Lukacs and Otto Szász, On analytic characteristic functions ...... 615

W. A. Mersman, Evaluation of an integral occurring in servomechanism theory.......................................... 627

Lawrence Edward Payne and Alexander Weinstein, Capacity, virtual mass, and generalized symmetrization......................... 633

Choy-Tak Taam, The boundedness of the solutions of a differential equation in the complex domain ...................................... 643 